\title{
Effectiveness of digital health interventions for diabetes: systematic review of systematic reviews
}

\author{
Bonkana Maiga ( $\sim$ bonkanamaiga@yahoo.fr) \\ Université des Sciences, des Techniques et des Technologies de Bamako \\ Cheick $O$ Bagayoko \\ DigiSanté-Mali, USTTB \\ Mohamed Ali Ag Ahmed \\ Université Laval \\ Abdrahamane Anne \\ DigiSanté-Mali, USTTB \\ Marie-Pierre Gagnon \\ University of Geneva \\ Sidibe Assa Traoré \\ Université des Sciences, des Techniques et des Technologies de Bamako \\ Jean François Landrier \\ Aix Marseille University, INRAE, INSERM \\ Antoine Geissbuhler \\ University of Geneva
}

\section{Research Article}

Keywords: diabetes, Digital health, e-health interventions, diabetes indicators, m-health

Posted Date: July 15th, 2021

DOI: https://doi.org/10.21203/rs.3.rs-722330/v1

License: @ (1) This work is licensed under a Creative Commons Attribution 4.0 International License. Read Full License

Version of Record: A version of this preprint was published at African Journal of Diabetes Medicine on January 1st, 2021. See the published version at https://doi.org/10.54931/2053-4787.29-S1-4. 


\section{Abstract \\ Background}

The use of digital health technologies to tackle diabetes has been particularly flourishing in recent years. Previous studies have shown to varying degrees that these technologies can have an impact on diabetes prevention and management.

\section{Objective}

The aim of this review is to summarize the best evidence regarding the effectiveness of digital health interventions to improve one or more diabetes indicators.

\section{Methods}

We included all types of interventions aimed at evaluating the effect of digital health on diabetes. We considered at all types of digital interventions (mobile health, teleconsultations, tele-expertise, electronic health records, decision support systems, e-learning, etc.). We included systematic reviews published in English or French over the last 29 years, from January 1991 to December 2019, that met the inclusion criteria. Two reviewers independently reviewed the titles and abstracts of the studies to assess their eligibility, and extracted relevant information according to a predetermined grid. Any disagreement was resolved by discussion and consensus between the two reviewers, or involved a third author as referee.

\section{Results}

In total in our review of journals, we included 10 reviews. The outcomes of interest were clinical indicators of diabetes that could be influenced by digital interventions. These outcomes had to be objectively measurable indicators related to diabetes surveillance and management that are generally accepted by diabetes experts. Six of the ten reviews showed moderate to large significant reductions in glycated hemoglobin (HBA1c) levels compared to controls. Most reviews reported overall positive results and found that digital health interventions improved health care utilization, behaviours, attitudes, knowledge and skills.

\section{Conclusion}

Based on a large corpus of scientific evidence on digital health interventions, this overview could help identify the most effective interventions to improve diabetes indicators.

\section{Background}

According to the International Diabetes Federation (IDF), 425 million people were living with diabetes in 2017, and by 2045, this figure will rise to 628 million people, more than $80 \%$ in low- and middle-income countries (1). According to recent projections of global mortality world-wide, diabetes will become the 7th leading cause of death by 2030 (2). The prospects in terms of solutions to fight diabetes remain a topical issue for all stakeholders (scientists, professionals, decision makers and patients). For several experts, new technologies are now presenting themselves as a credible solution (3). The WHO is on the front line (4) and some countries such as France have taken the lead by legislating (5). Today, the Internet is a widely accessible means of promoting health and managing chronic diseases. The number of scientific publications on ICT, a $\mathrm{m}$ - health, e-health has increased considerably over the last decade $(6-10)$, based on the use of the internet, mobile phones and computers to support lifestyle changes for people living with diabetes.

A systematic review of Internet-focused interventions aimed to identify Internet-based lifestyle modification interventions in adults with type 2 diabetes (11) demonstrated an improvement in diet and metabolic indicators in diabetic patients. Two meta-analyses, coupled with a narrative report of randomized controlled trials, examined the use of health Digital health to improve self-management skills and evaluated the effect of mobile phone intervention on glycemic control in people with diabetes $(11,13)$. They found an improvement in self-management skills and documented an average decrease in fly-coated hemoglobin of $0.14 \mathrm{mil}$ ) and blood glucose of $0.33 \mathrm{mmol}$ ). Two systematic reviews, one based on web-based programs and the use of technology to promote physical activity in T2DM $(14,15)$. 
These reviews sought to identify behaviour change techniques (BCTs) that are applied in web-based self-management and physical activity promotion programs and their effectiveness in relation to predefined health outcomes. Based on their results, it appears that it is still difficult to know which BCTs are effective in improving diabetes self-management and physical activity. "Other studies have focused on specific technologies (e.g. telemedicine, decision support tool« Other studies have focused on specific technologies (e.g. telemedicine, decision support tool, electronic medical record) to support diabetes care. » However, evaluation of these interventions to improve the quality of diabetes care in low-resource countries is largely lacking.

Over the past 30 years, the effectiveness of digital health interventions in the field of diabetes has been assessed. Our aim is to synthesize this large body of evidence to demonstrate the importance of digital health in the prevention and management of diabetes. Conducting a systematic review of systematic reviews will allow to summarize and analyze the scientific evidence regarding the surveillance, treatment and prevention of diabetes complications.

\section{Methods}

As a first step, we conducted bibliographic searches on PubMed® and Google Scholar. Several terms related to the effectiveness of digital health interventions for diabetes were searched on PubMed $\circledast$ and Google Scholar namely Papers published between January 1990 and December 2019 were considered. In a second step, we searched the references listed in the articles collected through previous searches.

We included systematic reviews that evaluated and described the effects of digital health on diabetes management indicators, regardless of the type of diabetes and the type of interventions. Those published in English or French over the last 30 years (19912019), since we considered that the Internet was not widely available prior to 1991. Reviews clearly describing the method used to select studies were selected. We included reviews that used systematic search strategies to identify the selected studies, had a systematic presentation, and provided a summary of the results and main characteristics of the included studies.

Following the literature search and the reading of the selected articles or abstracts, a synthesis table was produced. It indicated the references of the articles (author, year, name of the journal), the objective of the study, the study population, the methods used, the definition of the variables of interest, the exposure variables, the main and secondary results, the limitations of the study as well as any comments related to the study (adjustments, definitions, classifications used). Given the length of the table and by way of example, an extract concerning two selected articles is available in Supplemental data. A second table summarizing all the factors that were found to be associated with the effectiveness of Digital health for diabetes, related in the studies, as well as the definitions and modalities used for each of these variables was also produced.

\section{Results}

Epidemiological studies have been conducted to describe the characteristics of ICT-based interventions and identify those associated with diabetes. Several of these studies used data from pilot interventions. However, most of them sought factors positively associated with the management and prevention of diabetes-related complications through cross-sectional analyses, i.e. comparing users and health ICT solutions at inclusion or over a given period of time. Although a few longitudinal analyses have focused on factors preventing complications or glycemic control in people with diabetes.

The first query had yielded $\mathbf{7 7 6 1}$ results. When Google Scholar the same query on the same date gave $\mathbf{4 2 3 0}$ results. Most of the articles obtained did not correspond to the objective of the search, duplicates, so a selection was made on the basis of titles and then summaries. The articles most relevant to the search were read in full. Thus, query 2 was implemented. It counted $\mathbf{1 1 7}$ articles including some from the first query. The articles had to be written in English or French ( 5 articles were excluded on this criterion). They also had to provide information on ICT and diabetes. A total of 10 full-text articles and 2 abstracts were selected.

\section{Figure 1 : Records selection processes and results}

\section{Table 1 : Classification according to the overall outcomes}


Across included reviews, there were 22 trials that made reference to clinical data and Digital health: Internet, telephone (12), computerassisted integration of clinical data information (16).

Six out of 14 interventions showed moderate, significant decreases in hemoglobin HBA1c compared to controls. The results of the metaanalyses revealed that ICT use was associated with significant reductions in HbA1c levels, blood pressure, total cholesterol, and triglycerides compared with usual care. A meta-analysis involving 1657 participants showed that mobile phone; diabetes selfmanagement interventions reduced $\mathrm{HbA} 1 \mathrm{c}$ values by a mean of $0.5 \%$ [6 mmol/l; $95 \%$ Confidence Interval, 0.3-0.7\% (4-8 mmol/l)] over a median follow-up time of 6 months (13).

In subgroup analysis, 11 reviews in patients with type 2 diabetes reported significantly greater reductions in HbA1c than studies in patients with type 1 diabetes [0.8 $(9 \mathrm{mmol} / \mathrm{l})$ vs. $0.3 \%(3 \mathrm{mmol} / \mathrm{l}) ; \mathrm{P}=0.02]$. The effect of the mobile phone intervention did not differ significantly from other participant characteristics or intervention strategies. Another review of 40 eligible studies, in which glycated hemoglobin, and blood glucose levels were reported, showed significant improvement in 7 and 6 trials, respectively (26). A significant improvement in compliance was found in 6 of the 8 computerized incentive studies. Meta-analysis of studies using home blood glucose records in insulin dose adjustment documented a mean decrease in glycated hemoglobin of $0.14 \mathrm{mmol} / \mathrm{L}(95 \% \mathrm{Cl}, 0.11-1.16)$, and a decrease in blood glucose of $0.33 \mathrm{mmol} / \mathrm{L}(95 \% \mathrm{Cl}, 0.28-0.39)(29)$. Several computerized educational programs improved metabolic indicators.

One of the included review had retained only 9 studies based on its inclusion criteria. Of the nine, two studies demonstrated improvements in glycemic control.

\section{Table 2: Clinical Outcomes and the Use of Digital health in Health Care}

\section{Dietary Outcomes and Behavioural Changes}

Several computer-based educational programs have been shown to significantly improve the diets and behaviours of people living with diabetes, particularly type 2 diabetes $(11,17)$. We identified reviews of 37 included studies, including 13 trials, based on the link between ICT and diet and behaviour change (15). In the same review cited above, which focused on randomized trials, improvements in diet and/or physical activity were found in comparison with a control group. Successful studies were interactive components based on theory, with personalized follow-up and feedback, and provided opportunities for peer support. Use of the site decreased over time in all studies. Few studies focused on high-risk and underserved populations(14).

In the second review, which included 15 eligible studies, interventions were delivered through Internet, mobile phone, CD-ROM and computer (18). These studies showed an increase in physical activity, but only nine were significant.

\section{Table 3: Eating Outcomes and Behavior Change}

\section{Discussion}

Our review provides a state of the art on the issue of the effectiveness of Digital health in the monitoring and prevention of diabetes. To date, we find many reviews and studies on the use of Digital health in diabetes around the world, but no studies seem to highlight the use of Digital health in Africa on non-communicable diseases, particularly diabetes.

Following the final decision to include the studies in the review, data extraction was performed by two independent individuals. We used a data collection form (AMSTAR) that allowed us to collect all of the data needed to analyze the studies, such as eligibility criteria, methods, participants, interventions, judging criteria, or outcomes. Risks of bias were also extracted in order to assess the level of evidence for each study. Once all the data was extracted and collected in the collection form, we used Microsoft Excel data management software to prepare the data analysis. 
The data were synthesized in a qualitative and descriptive manner. We did not conduct a meta-analysis, as the set of studies was not homogeneous. For this reason, we opted for a descriptive synthesis. One of the limitations of the chosen methodology could be completeness, as it is quite possible that published or unpublished evidence may not have been uncovered either due to lack of access orin error.

The results of this review consolidate the growing body of thinking that emerging Digital health can improve the prevention and management of diabetes-related diseases. Digital health are a rapidly developing tool in improving the care process for patients with type 2 diabetes, as these significant healthcare outcomes indicate (12).

These results must be put into perspective with respect to the decrease in HbA1c levels and other clinical outcomes (i.e. lipids) (34). Although these findings are consistent with reviews of type 1 diabetes in terms of psychological and biological outcomes, a formal meta-analysis conducted primarily in type 1 diabetes supports the hypothesis that computer systems can effectively improve metabolic control (35).

Internet-assisted diabetic patients, usually focused on education, should assess their HbA1c, health care utilization and costs associated with the intervention (11). By mode of delivery, Internet-based interventions have a positive impact on patient-centred outcomes. Unfortunately, however, they have not been evaluated in health care utilization and clinical outcomes. Telephone interventions had a positive impact on primary care visits. Computer-assisted integration of clinical management also had a positive impact on most health care utilization outcomes $(10,36)$. While several interventions resulted in significant reductions in HbA1c, there was no clear pattern by mode, and many studies reported no significant change in HbA1c.

A recent review by Farmer et al. evaluated the feasibility, acceptability and effectiveness of telemedicine used to support self-monitoring of blood glucose levels by transmitting results from a server with automated or clinician feedback (6. The results judged telemedicine to be feasible and acceptable, but the evidence for its effectiveness in improving diabetes management was not considered strong. Although the main objective of the review and the inclusion/exclusion criteria led to a set of studies, which differed from this review, the results are consistent with our findings related to telemedicine interventions and $\mathrm{HbA} 1 \mathrm{c}$.

Computerized knowledge management is becoming a vital component of quality diabetes care. It promotes procedure monitoring, computerized adjustment of home insulin therapy, blood glucose records, remote feedback and documented advice benefits of improved diabetes outcomes $(11,37,38)$. There is growing evidence that information technology can improve diabetes care. Future research should characterize the long-term benefits, establish methods to evaluate clinical outcomes and determine the costeffectiveness of ICT use.

There is a clear need for more comprehensive interventions, in which multiple technologies are integrated, to manage chronic diseases such as diabetes. These ICT interventions should be theoretically based, and based on user-centred socio-technical design principles, in their planning, design, and implementation. The effectiveness of self-management systems should be evaluated according to several main criteria: motivation for self-management, long-term adherence, cost, uptake, satisfaction, and outcomes as an end result. The use of ICT in supporting diabetes self-management appears to have potential benefits for patient self-management of diabetes. However, the effectiveness of technologies to improve patient outcomes is still awaiting confirmation in future studies.

The combined results of the included trials have provided strong evidence that a mobile phone intervention can lead to statistical analysis significantly improving glycemic control and self-management in the treatment of diabetes, particularly in patients with type 2 diabetes (6). This review reinforces the need for well-designed surveys to assess the role and feasibility of interventional technologies in clinical decision-making for diabetes care.

In a context of limited resources, individual economic difficulties, lack of structured systems or skilled human capital in Africa. ICT can be a credible alternative for improving diabetes management. However, future research is needed on the use of ICT interventions in underserved communities, examining patterns of use and user engagement over time. Today, new technologies are increasingly present in the health field (E-Health and m-health). In Africa, from 2007 to the present day, the adoption of new technologies has had undeniable positive effects on the socio-economic development of the continent, the most striking example being mobile telephony. According to a 2013 study by the World Association of Telecom Operators (GSMA), the number of mobile subscribers in Africa grew by almost $20 \%$ per year between 2007 and 2012).

Information and communication technologies (Digital health) have the potential to improve care for chronic diseases, provide better health outcomes and reduce direct and indirect costs. However, realizing these gains requires new forms of care delivery through the 
adoption of Digital health. The specific choice of Digital health and changes to existing forms of health care delivery. Achieving these new modes of delivery requires appropriate payment policies. Future authors should review the literature on health care payment and Digital health in chronic care and then apply a specific theoretical economic analysis of how Digital health are changing health care payment policy recommendations. Using diabetes as an example, they should identify and illustrate the characteristics of the disease and technology that determine the optimal payment method. Overall, Digital health are changing the optimal combination of fee-forservice and capitation towards greater capitation. Exclusions for ICT-supported preventive care allow for more powerful payment while addressing selection issues (39).

Primary and secondary prevention is a major focus in the fight against diabetes, in line with the overall objective of promoting, among people at risk or with diabetes. Good behaviour in terms of diet and physical activity. The issue of prevention is linked to a balanced diet and physical activity Digital health offer interesting perspectives with the benefit of reaching the greatest number of people and on a continuous basis. A relatively small number of online self-management support programs for WD2 have been reported using only a selected number of behaviours (physical activity, diet). Technology-based interventions to promote physical activity are effective. Methods to promote participant adherence is associated with greater benefit. The development of future online self-management interventions should be based on the use of theories, and behaviour changes should be accurately reported. Future research should focus on strategies to improve adherence and sustainability to increase the effectiveness of technology-based physical activity interventions in diabetes treatment.

New technologies in health care in Africa are in the making. They would appear today as a real lever for improving health. Africa will only be able to reap the benefits of digital technology on its health if everyone is involved: researchers, donors, public authorities, the private sector in order to create favourable conditions.

\section{Regarding the limits of our study}

We could not appreciate an in-depth analysis taking into account, for example, the expenditure related to the use of ICT in the management of diabetes. But also the impact that their uses could have on the time of the management of diabetes. Our future investigations will focus on responding to these limits

\section{Conclusion}

This review allowed us to synthesize and update information on the use of Digital health in diabetes management and monitoring, and to provide several implications for future research on the use of Digital health in diabetes. Our review suggests that ICT could be an important tool and should be further evaluated for its potential to improve diabetes care. On the other hand, studies should consider participants' perceptions of diabetes self-management, as Digital health can likely be a component of care that depends on patient acceptance. There is also a need to improve the quality of studies and the communication of results.

Based on this review, we strongly recommend that future studies, particularly in Africa, should 1) favour designs that allow comparisons with a concurrent control group with a less biased assessment of the effectiveness of these interventions; 2) study the long-term effects of these interventions; 3 ) address and report on the costs associated with the intervention and the resulting cost-effectiveness; and 4) include a representative number of minority and underserved populations and determine whether these interventions are equally effective in these groups.

\section{Declarations}

\section{Consent for publication}

The publication of this work was authorized all the research staff.

\section{Availability of data and materials}

The datasets used and/or analysed during the current study are available from the corresponding author on reasonable request

\section{Competing interests}

The authors declare that there are no confldigital health of interest regarding the publication of this paper. 
$\mathrm{BM}, \mathrm{COB}, \mathrm{MAA}, \mathrm{AA}, \mathrm{MPG}$, and OF designed the study. BM and COB draft the first version. All authors revised the first draft of the manuscript. BM, $\mathrm{COB}$, and MAA carried out the second draft of the manuscript.. All the authors revised the manuscript. BM draft the final version of the manuscript. All authors checked and approved the submitted manuscript

\section{References}

1. IDF Atlas 9th edition and other resources [Internet]. [cité 5 févr 2020]. Disponible sur: https://diabetesatlas.org/en/resources/

2. OMS | Rapport mondial sur le diabète [Internet]. WHO. [cité 5 févr 2020]. Disponible sur: http://www.who.int/diabetes/globalreport/fr/

3. Benhamou P-Y, Muller M, Lablanche S, Debaty I. La télémédecine au service de la prise en charge des patients diabétiques : développements actuels et conditions du succès. European Research in Telemedicine / La Recherche Européenne en Télémédecine. 1 mars 2013;2(1):23-8.

4. LE MOBILE AU SERVICE DE LA LUTTE CONTRE LE DIABETE | m-Diabète [Internet]. [cité 5 févr 2020]. Disponible sur: http://mdiabete.gouv.sn/

5. DGOS. La télémédecine [Internet]. Ministère des Solidarités et de la Santé. 2020 [cité 20 avr 2020]. Disponible sur: http://solidarites-sante.gouv.fr/soins-et-maladies/prises-en-charge-specialisees/telemedecine/article/la-telemedecine

6. Farmer A, Gibson OJ, Tarassenko L, Neil A. A systematic review of telemedicine interventions to support blood glucose selfmonitoring in diabetes. Diabet Med. oct 2005;22(10):1372-8.

7. Ming W-K, Mackillop LH, Farmer AJ, Loerup L, Bartlett K, Levy JC, et al. Telemedicine Technologies for Diabetes in Pregnancy: A Systematic Review and Meta-Analysis. J Med Internet Res. 09 2016;18(11):e290.

8. Talbot TB. Virtual reality and interactive gaming technology for obese and diabetic children: is military medical technology applicable? J Diabetes Sci Technol. 1 mars 2011;5(2):234-8.

9. Sweileh WM, Al-Jabi SW, AbuTaha AS, Zyoud SH, Anayah FMA, Sawalha AF. Bibliometric analysis of worldwide scientific literature in mobile - health: 2006-2016. BMC Med Inform Decis Mak [Internet]. 30 mai 2017 [cité 13 nov 2018];17. Disponible sur: https://www.ncbi.nlm.nih.gov/pmc/articles/PMC5450106/

10. Fortmann AL, Gallo LC, Garcia MI, Taleb M, Euyoque JA, Clark T, et al. Dulce Digital: An mHealth SMS-Based Intervention Improves Glycemic Control in Hispanics With Type 2 Diabetes. Diabetes Care. 1 oct 2017;40(10):1349-55.

11. Cotter AP, Durant N, Agne AA, Cherrington AL. Internet interventions to support lifestyle modification for diabetes management: a systematic review of the evidence. J Diabetes Complicat. avr 2014;28(2):243-51.

12. El-Gayar O, Timsina P, Nawar N, Eid W. A systematic review of IT for diabetes self-management: are we there yet? Int J Med Inform. août 2013;82(8):637-52.

13. Liang X, Wang Q, Yang X, Cao J, Chen J, Mo X, et al. Effect of mobile phone intervention for diabetes on glycaemic control: a meta-analysis. Diabet Med. avr 2011;28(4):455-63.

14. Connelly J, Kirk A, Masthoff J, MacRury S. The use of technology to promote physical activity in Type 2 diabetes management: a systematic review. Diabet Med. déc 2013;30(12):1420-32.

15. van Vugt M, de Wit M, Cleijne WHJJ, Snoek FJ. Use of behavioral change techniques in web-based self-management programs for type 2 diabetes patients: systematic review. J Med Internet Res. 13 déc 2013;15(12):e279.

16. Balas EA, Krishna S, Kretschmer RA, Cheek TR, Lobach DF, Boren SA. Computerized knowledge management in diabetes care. Med Care. juin 2004;42(6):610-21.

17. Dalton JE. Web-based care for adults with type 2 diabetes. Can J Diet Pract Res. 2008;69(4):185-91. 
18. Ali MK, Shah S, Tandon N. Review of electronic decision-support tools for diabetes care: a viable option for low- and middleincome countries? J Diabetes Sci Technol. 1 mai 2011;5(3):553-70.

19. GSMA [Internet]. GSMA. [cité 5 févr 2020]. Disponible sur: https://www.gsma.com/

20. Malaria diagnosis and mapping with $m$-Health and geographic information systems (GIS): evidence from Uganda | Malaria Journal | Full Text [Internet]. [cité 22 avr 2020]. Disponible sur: https://malariajournal.biomedcentral.com/articles/10.1186/s12936-016$1546-5$

21. Sarfo FS, Treiber F, Jenkins C, Patel S, Gebregziabher M, Singh A, et al. Phone-based Intervention under Nurse Guidance after Stroke (PINGS): study protocol for a randomized controlled trial. Trials. 5 sept 2016;17(1):436.

22. Where there is no phone: The benefits and limitations of using intermediaries to extend the reach of mHealth to individuals without personal phones in Malawi | Larsen-Cooper | African Population Studies [Internet]. [cité 22 avr 2020]. Disponible sur: https://aps.journals.ac.za/pub/article/view/714

23. Forrest JI, Wiens M, Kanters S, Nsanzimana S, Lester RT, Mills EJ. Mobile health applications for HIV prevention and care in Africa. Current Opinion in HIV and AIDS. nov 2015;10(6):464-471.

24. Hao W-R, Hsu Y-H, Chen K-C, Li H-C, Iqbal U, Nguyen P-A, et al. LabPush: A pilot study of providing remote clinics with laboratory results via short message service (SMS) in Swaziland, Africa - A qualitative study. Computer Methods and Programs in Biomedicine. 1 janv 2015;118(1):77-83.

25. Hampshire K, Porter G, Owusu SA, Mariwah S, Abane A, Robson E, et al. Informal m-health: How are young people using mobile phones to bridge healthcare gaps in Sub-Saharan Africa? Soc Sci Med. oct 2015;142:90-9.

26. Beran D, Yudkin JS, de Courten M. Assessing health systems for type 1 diabetes in sub-Saharan Africa: developing a « Rapid Assessment Protocol for Insulin Access ». BMC Health Serv Res. 24 févr 2006;6(1):17.

27. Bagayoko C-O, Bediang G, Anne A, Niang M, Traoré A-K, Geissbuhler A. Digital health and the need to develop centers of expertise in sub-Saharan Africa : two examples in Mali and Cameroon. Med Sante Trop. 1 nov 2017;27(4):348-53.

28. Jackson CL, Bolen S, Brancati FL, Batts-Turner ML, Gary TL. A systematic review of interactive computer-assisted technology in diabetes care. Interactive information technology in diabetes care. J Gen Intern Med. févr 2006;21(2):105-10.

29. Or CKL, Tao D. Does the use of consumer health information technology improve outcomes in the patient self-management of diabetes? A meta-analysis and narrative review of randomized controlled trials. Int J Med Inform. mai 2014;83(5):320-9.

30. Edwards L, Thomas C, Gregory A, Yardley L, O'Cathain A, Montgomery AA, et al. Are people with chronic diseases interested in using telehealth? A cross-sectional postal survey. J Med Internet Res. 8 mai 2014;16(5):e123.

33. Bagayoko C-O, Niang M, Anne A, Traoré D, Sangho H, Traoré A-K, et al. The delegation of tasks in the era of e-health to support community interventions in maternal and child health: lessons learned from the PACT-Denbaya project. Médecine et Santé Tropicales. 201710-11-12;(4):354-359.

34. Sarfati D, McLeod M, Stanley J, Signal V, Stairmand J, Krebs J, et al. BetaMe: impact of a comprehensive digital health programme on $\mathrm{HbA} 1 \mathrm{c}$ and weight at 12 months for people with diabetes and pre-diabetes: study protocol for a randomised controlled trial. Trials. 5 mars 2018;19(1):161.

35. Montani S, Bellazzi R, Quaglini S, d'Annunzio G. Meta-analysis of the effect of the use of computer-based systems on the metabolic control of patients with diabetes mellitus. Diabetes Technol Ther. 2001;3(3):347-56.

36. Arora S, Peters AL, Burner E, Lam CN, Menchine M. Trial to examine text message-based mHealth in emergency department patients with diabetes (TExT-MED): a randomized controlled trial. Ann Emerg Med. juin 2014;63(6):745-754.e6.

37. Cassimatis M, Kavanagh DJ. Effects of type 2 diabetes behavioural telehealth interventions on glycaemic control and adherence: a systematic review. J Telemed Telecare. déc 2012;18(8):447-50.

Page 8/13 
38. Castelnuovo G, Manzoni GM, Cuzziol P, Cesa GL, Corti S, Tuzzi C, et al. TECNOB Study: Ad Interim Results of a Randomized Controlled Trial of a Multidisciplinary Telecare Intervention for Obese Patients with Type-2 Diabetes. Clin Pract Epidemiol Ment Health. 4 mars 2011;7:44-50.

39. Cronquist Christensen M, Remler D. Information and communications technology in chronic disease care: what are the implications for payment? Med Care Res Rev. avr 2007;64(2):123-47.

\section{Tables}

Table 1 : Classification according to the overall outcomes:

\begin{tabular}{|c|c|c|c|c|}
\hline $\mathbf{N}^{\circ}$ & Autors & Outcomes & Intervention/ Type of technologies & Number participants \\
\hline 1 & $\begin{array}{l}\text { Or et } \\
\text { Tao } \\
2014\end{array}$ & $\begin{array}{l}\text { Patient self-management of } \\
\text { diabetes }\end{array}$ & $\begin{array}{l}\text { Consumer health information } \\
\text { technologies (CHITs }\end{array}$ & $\begin{array}{c}\text { Sixty-two studies, } \\
\text { representing } 67 \text { RCTs, met } \\
\text { the inclusion criteria }\end{array}$ \\
\hline 2 & $\begin{array}{l}\text { Cotter } \\
\text { et al } \\
2013\end{array}$ & $\begin{array}{l}\text { Among adults with type } 2 \\
\text { diabetes. }\end{array}$ & $\begin{array}{l}\text { Internet based interventions to } \\
\text { promote lifestyle } \\
\text { modification }\end{array}$ & $\begin{array}{l}\text { Of the } 2803 \text { papers } \\
\text { identified, nine met } \\
\text { inclusion criteria. }\end{array}$ \\
\hline 3 & $\begin{array}{l}\text { Connely } \\
\text { et al } \\
2013\end{array}$ & Type 2 diabetes & $\begin{array}{l}\text { Technology included mobile phones } \\
\text { and text messages, websites, CD- } \\
\text { ROMs and computer-learning-based } \\
\text { technology, }\end{array}$ & $\begin{array}{l}\text { In total, } 15 \text { articles were } \\
\text { eligible for review }\end{array}$ \\
\hline 4 & $\begin{array}{l}\text { Van } \\
\text { Gugt et } \\
\text { al } 2013 \\
\end{array}$ & $\begin{array}{l}\text { diabetes self-management } \\
\text { behaviors and related health } \\
\text { outcomes }\end{array}$ & $\begin{array}{l}\text { Online diabetes self-management } \\
\text { tools and programs, }\end{array}$ & Among 40 eligible studies, \\
\hline 5 & $\begin{array}{l}\text { Omar } \\
\text { El- } \\
\text { Gayara } \\
\text { et al } \\
2013 \text {, }\end{array}$ & $\begin{array}{c}\text { self-management for Type } 1 \text { and } \\
\text { Type } 2 \text { diabetes }\end{array}$ & Information technology & $\begin{array}{l}\text { A total of } 104 \text { studies were } \\
\text { included.. }\end{array}$ \\
\hline 6 & $\begin{array}{l}\text { Ali et al } \\
2011\end{array}$ & $\begin{array}{l}\text { Physician performance and patient } \\
\text { outcomes }\end{array}$ & Applicability in LMICs & $\begin{array}{l}33 \text { studies met inclusion } \\
\text { criteria }\end{array}$ \\
\hline 7 & $\begin{array}{l}\text { Liang et } \\
\text { al } 2010\end{array}$ & Diabetes or diabetes Mellitus & $\begin{array}{l}\text { Mobile phone or cellular phone, or } \\
\text { text message }\end{array}$ & $\begin{array}{l}\text { A total of } 22 \text { trials were } \\
\text { selected for the review. }\end{array}$ \\
\hline 8 & $\begin{array}{l}\text { Dalton } \\
\text { et al } \\
2008\end{array}$ & $\begin{array}{l}\text { Telediabetes is a form of } \\
\text { telemedicine used to provide } \\
\text { information and client care to } \\
\text { people with diabetes. }\end{array}$ & Cellular telephones and/or computers & $\begin{array}{l}\text { Nine articles meeting the } \\
\text { inclusion criteria were } \\
\text { identified, critiqued, and } \\
\text { summarized. }\end{array}$ \\
\hline 9 & $\begin{array}{l}\text { Jacksson } \\
\text { et al } \\
2006 \\
\end{array}$ & type 2 diabetes & Information Technology (IT) & There were 26 studies. \\
\hline 10 & $\begin{array}{l}\text { Balas et } \\
\text { al } 2004\end{array}$ & $\begin{array}{l}\text { Patient outcomes and to enable } \\
\text { this knowledge to be incorporated } \\
\text { into diabetes care practice }\end{array}$ & $\begin{array}{l}\text { automated information interventions } \\
\text { on diabetes }\end{array}$ & Among 40 eligible studies, \\
\hline
\end{tabular}

Table 2: Clinical Outcomes and the Use of Digital health in Health Care

\begin{tabular}{|l|l|l|l|l|l|l|}
\hline $\begin{array}{l}\text { Author, } \\
\text { year }\end{array}$ & Objective & Outcome & $\begin{array}{l}\text { Definition } \\
\text { of } \\
\text { intervention }\end{array}$ & $\begin{array}{l}\text { Number of studies } \\
\text { included }\end{array}$ & $\begin{array}{l}\text { Summary of } \\
\text { results }\end{array}$ & $\begin{array}{l}\text { Authors' } \\
\text { conclusions }\end{array}$ \\
\hline
\end{tabular}




\begin{tabular}{|c|c|c|c|c|c|c|}
\hline $\begin{array}{l}\text { Or et } \\
\text { Tao } \\
2014\end{array}$ & $\begin{array}{l}\text { To } \\
\text { synthesize } \\
\text { evidence } \\
\text { from } \\
\text { randomized } \\
\text { controlled } \\
\text { trials (RCTs) } \\
\text { on the } \\
\text { effects of } \\
\text { Consumer } \\
\text { health } \\
\text { information } \\
\text { technologies } \\
\text { (CHITs) on } \\
\text { patient } \\
\text { outcomes }\end{array}$ & $\begin{array}{l}\text { Patient self- } \\
\text { management } \\
\text { of diabetes }\end{array}$ & $\begin{array}{l}\text { Consumer } \\
\text { health } \\
\text { information } \\
\text { technologies } \\
\text { (CHITs) }\end{array}$ & $\begin{array}{l}62 \text { studies, } \\
\text { representing } \\
67 \text { RCTs, } \\
\text { met the } \\
\text { inclusion } \\
\text { criteria }\end{array}$ & $\begin{array}{l}\text {. The results of the meta- } \\
\text { analyses showed that the } \\
\text { use of CHITs was } \\
\text { associated with } \\
\text { significant reductions in } \\
\text { HbA1c, blood pressure, } \\
\text { total cholesterol, and } \\
\text { triglycerides levels when } \\
\text { compared with usual } \\
\text { care. The findings from } \\
\text { the narrative synthesis } \\
\text { indicated that only a } \\
\text { small proportion of the } \\
\text { trials reported positive } \\
\text { effects of CHITs on } \\
\text { patient outcomes. }\end{array}$ & $\begin{array}{l}\text { The use of CHITs in } \\
\text { supporting diabetes } \\
\text { self-management } \\
\text { appears to have } \\
\text { potential benefits for } \\
\text { patients' self- } \\
\text { management of } \\
\text { diabetes. However, the } \\
\text { effectiveness of the } \\
\text { technologies in } \\
\text { improving patient } \\
\text { outcomes still awaits } \\
\text { confirmation in future } \\
\text { studies. }\end{array}$ \\
\hline $\begin{array}{l}\text { Omar } \\
\text { El- } \\
\text { Gayara } \\
\text { et al } \\
2013 \text {, }\end{array}$ & $\begin{array}{l}\text { To } \\
\text { determine } \\
\text { how IT has } \\
\text { been used to } \\
\text { improve self- } \\
\text { management } \\
\text { for adults } \\
\text { with Type } 1 \\
\text { and Type2 } \\
\text { diabetes. }\end{array}$ & $\begin{array}{l}\text { self- } \\
\text { management } \\
\text { for Type } 1 \\
\text { and Type } 2 \\
\text { diabetes }\end{array}$ & $\begin{array}{l}\text { Information } \\
\text { technology }\end{array}$ & $\begin{array}{l}\text { A total of } \\
104 \text { studies } \\
\text { were } \\
\text { included.. }\end{array}$ & $\begin{array}{l}\text { Overall, } 74 \% \text { of studies } \\
\text { showed some form of } \\
\text { added benefit, } 13 \% \\
\text { articles showed no- } \\
\text { significant value provided } \\
\text { by IT, and } 13 \% \text { of articles } \\
\text { did not clearly define the } \\
\text { added benefitdue to IT. } \\
\text { Information technologies } \\
\text { used included the } \\
\text { Internet (47\%), cellular } \\
\text { phones } \\
\text { (32\%),telemedicine } \\
\text { (12\%), and decision } \\
\text { support techniques (9\%). } \\
\text { Limitations and research } \\
\text { gapsidentified include } \\
\text { usability, real-time } \\
\text { feedback, integration } \\
\text { with provider electronic } \\
\text { medicalrecord (EMR), as } \\
\text { well as analytics and } \\
\text { decision support } \\
\text { capabilities. }\end{array}$ & $\begin{array}{l}\text { There is a distinct need } \\
\text { for more comprehensive } \\
\text { interventions, in which } \\
\text { several technologies are } \\
\text { integrated in order to } \\
\text { be able to manage } \\
\text { chronic conditions such } \\
\text { as diabetes. Such IT } \\
\text { interventions should be } \\
\text { theoretically founded } \\
\text { and should rely on } \\
\text { principles of user- } \\
\text { centered and socio- } \\
\text { technical design in its } \\
\text { planning, design and } \\
\text { implementation. } \\
\text { Moreover, the } \\
\text { effectiveness of self- } \\
\text { management systems } \\
\text { should be assessed } \\
\text { along multiple } \\
\text { dimensions: motivation } \\
\text { for self-management, } \\
\text { long-term adherence, } \\
\text { cost, adoption, } \\
\text { satisfaction and } \\
\text { outcomes as a final } \\
\text { result. }\end{array}$ \\
\hline $\begin{array}{l}\text { Liang } \\
\text { et al } \\
2010\end{array}$ & $\begin{array}{l}\text { To assess } \\
\text { the effect of } \\
\text { mobile } \\
\text { phone } \\
\text { intervention } \\
\text { on glycaemic } \\
\text { control in } \\
\text { diabetes } \\
\text { self- } \\
\text { management }\end{array}$ & $\begin{array}{l}\begin{array}{l}\text { Diabetes or } \\
\text { diabetes }\end{array} \\
\text { Mellitus } \\
1657 \\
\text { participants } \\
\text { showed that } \\
\text { mobile } \\
\text { phone } \\
\text { interventions } \\
\text { for diabetes } \\
\text { self- } \\
\text { management }\end{array}$ & $\begin{array}{l}\text { Mobile } \\
\text { phone or } \\
\text { cellular } \\
\text { phone, or } \\
\text { text } \\
\text { message }\end{array}$ & $\begin{array}{l}\text { A total of } 22 \\
\text { trials were } \\
\text { selected for } \\
\text { the review. }\end{array}$ & $\begin{array}{l}\text { Meta-analysis among } \\
1657 \text { participants showed } \\
\text { that mobile phone } \\
\text { interventions for diabetes } \\
\text { self-management reduced } \\
\text { HbA1c values by amean } \\
\text { of } 0.5 \% \text { [6 mmol / mol; } \\
95 \% \text { confidence interval, } \\
0.3-0.7 \% \text { ( } 4-8 \text { mmol/ } \\
\text { mol)] over a median of } 6 \\
\text { months follow-up } \\
\text { duration. In subgroup } \\
\text { analysis, } 11 \text { studies } \\
\text { among Type } 2 \text { diabetes } \\
\text { patients reported } \\
\text { significantly greater } \\
\text { reduction in HbA1c than } \\
\text { studies among Type } 1 \\
\text { diabetes patients [0.8 (9 } \\
\text { mmol/ mol) vs. 0.3\% (3 } \\
\text { mmol / mol); } P \text { = } 0.02] \text {. } \\
\text { The effect of mobile } \\
\text { phone intervention did } \\
\text { not significantly differ by } \\
\text { other participant } \\
\text { characteristics or } \\
\text { intervention strategies }\end{array}$ & $\begin{array}{l}\text { Results pooled fromthe } \\
\text { included trials provided } \\
\text { stronge vidence that } \\
\text { mobile phone } \\
\text { intervention led to } \\
\text { statistically significant } \\
\text { improvement in } \\
\text { glycaemic control and } \\
\text { self-management in } \\
\text { diabetes care, } \\
\text { especially for Type } 2 \\
\text { diabetes patients. }\end{array}$ \\
\hline
\end{tabular}

Table 3: Eating Outcomes and Behavior Changes 


\begin{tabular}{|c|c|c|c|c|c|c|}
\hline $\begin{array}{l}\text { Author, } \\
\text { year }\end{array}$ & Objective & Outcome & $\begin{array}{l}\text { Definition of } \\
\text { Intervention }\end{array}$ & $\begin{array}{l}\text { Number of } \\
\text { studies } \\
\text { included }\end{array}$ & Summary of results & $\begin{array}{l}\text { Authors' } \\
\text { conclusions }\end{array}$ \\
\hline $\begin{array}{l}\text { Connely } \\
\text { et al } \\
2013\end{array}$ & $\begin{array}{l}\text { To provides a } \\
\text { systematic and } \\
\text { descriptive } \\
\text { assessment of the } \\
\text { effectiveness of } \\
\text { technology to } \\
\text { promote physical } \\
\text { activity in people } \\
\text { with Type } 2 \\
\text { diabetes. }\end{array}$ & $\begin{array}{l}\text { Type } 2 \\
\text { diabetes }\end{array}$ & $\begin{array}{l}\text { Technology } \\
\text { included } \\
\text { mobile } \\
\text { phones and } \\
\text { text } \\
\text { messages, } \\
\text { websites, CD- } \\
\text { ROMs and } \\
\text { computer- } \\
\text { learning- } \\
\text { based } \\
\text { technology, }\end{array}$ & $\begin{array}{l}\text { In total, } 15 \\
\text { articles were } \\
\text { eligible for } \\
\text { review }\end{array}$ & $\begin{array}{l}\text { web-based (9), mobile } \\
\text { phone (3), CD-ROM } \\
\text { (2) and computer } \\
\text { based (1). All studies } \\
\text { found an increase in } \\
\text { physical activity but } \\
\text { only nine were } \\
\text { significant. The use of } \\
\text { a personal coach, } \\
\text { logbooks and } \\
\text { reinforcement } \\
\text { strategies such as } \\
\text { phone calls and email } \\
\text { counselling were } \\
\text { found to be effective } \\
\text { components } \\
\text { for behaviour change. } \\
\text { No studies were } \\
\text { ranked as low in } \\
\text { terms of } \\
\text { methodological } \\
\text { quality. }\end{array}$ & $\begin{array}{l}\text { Technology- } \\
\text { based } \\
\text { interventions } \\
\text { to promote } \\
\text { physical } \\
\text { activity are } \\
\text { effective; } \\
\text { using further } \\
\text { methods to } \\
\text { promote } \\
\text { participant } \\
\text { adherence is } \\
\text { associated } \\
\text { with greater } \\
\text { benefit. } \\
\text { Further } \\
\text { research } \\
\text { should look } \\
\text { into } \\
\text { strategies to } \\
\text { enhance } \\
\text { adherence } \\
\text { and } \\
\text { sustainability } \\
\text { in order to } \\
\text { increase the } \\
\text { effectiveness } \\
\text { of technology- } \\
\text { based } \\
\text { physical } \\
\text { activity } \\
\text { intervention } \\
\text { in } \\
\text { diabetes care. }\end{array}$ \\
\hline $\begin{array}{l}\text { Cotter } \\
\text { et al } \\
2013\end{array}$ & $\begin{array}{l}\text { The Internet } \\
\text { presents a widely } \\
\text { accessible, } 24 \text {-h } \\
\text { means to promote } \\
\text { chronic disease } \\
\text { management. } \\
\text { The objective of this } \\
\text { review is to identify } \\
\text { studies that used } \\
\text { Internet based } \\
\text { interventions to } \\
\text { promote } \\
\text { lifestylemodification } \\
\text { among adults with } \\
\text { type } 2 \text { diabetes. }\end{array}$ & $\begin{array}{l}\text { Among } \\
\text { adults with } \\
\text { type } 2 \\
\text { diabetes. }\end{array}$ & $\begin{array}{l}\text { Internet } \\
\text { based } \\
\text { interventions } \\
\text { to promote } \\
\text { lifestyle } \\
\text { modification }\end{array}$ & $\begin{array}{l}\text { Of the } 2803 \\
\text { papers } \\
\text { identified, } \\
\text { nine met } \\
\text { inclusion } \\
\text { criteria. }\end{array}$ & $\begin{array}{l}\text { Two studies } \\
\text { demonstrated } \\
\text { improvements in } \\
\text { diet and/or physical } \\
\text { activity and two } \\
\text { studies demonstrated } \\
\text { improvements in } \\
\text { glycemic control } \\
\text { comparing web-based } \\
\text { intervention with } \\
\text { control. Successful } \\
\text { studies were theory- } \\
\text { based, included } \\
\text { interactive } \\
\text { components with } \\
\text { tracking and } \\
\text { personalized } \\
\text { feedback, and } \\
\text { provided } \\
\text { opportunities for peer } \\
\text { support. Website } \\
\text { utilization declined } \\
\text { over time in all } \\
\text { studies that reported } \\
\text { on it. Few studies } \\
\text { focused on high risk, } \\
\text { underserved } \\
\text { populations. }\end{array}$ & $\begin{array}{l}\text { Web-based } \\
\text { strategies } \\
\text { provide a } \\
\text { viable option } \\
\text { for } \\
\text { facilitating } \\
\text { diabetes self- } \\
\text { management. } \\
\text { Future } \\
\text { research is } \\
\text { needed on } \\
\text { the use of } \\
\text { web-based } \\
\text { interventions } \\
\text { in } \\
\text { underserved } \\
\text { communities } \\
\text { and studies } \\
\text { examining } \\
\text { website } \\
\text { utilization } \\
\text { patterns and } \\
\text { engagement } \\
\text { over time. }\end{array}$ \\
\hline $\begin{array}{l}\text { Van } \\
\text { Gugt et } \\
\text { al } 2013\end{array}$ & $\begin{array}{l}\text { To identify which } \\
\text { BCTs are being } \\
\text { applied in online } \\
\text { self-management } \\
\text { programs for T2DM } \\
\text { and whether there } \\
\text { is indication of their } \\
\text { effectiveness in } \\
\text { relation to }\end{array}$ & $\begin{array}{l}\text { diabetes } \\
\text { self- } \\
\text { management } \\
\text { behaviors } \\
\text { and related } \\
\text { health } \\
\text { outcomes }\end{array}$ & $\begin{array}{l}\text { Online } \\
\text { diabetes self- } \\
\text { management } \\
\text { tools and } \\
\text { programs, }\end{array}$ & & $\begin{array}{l}\text { They found } 13 \\
\text { randomized controlled } \\
\text { trials reporting on } 8 \\
\text { online self- } \\
\text { management } \\
\text { interventions for } \\
\text { T2DM. The BCTs used } \\
\text { were feedback on } \\
\text { performance, }\end{array}$ & $\begin{array}{l}\text { Relatively } \\
\text { small number } \\
\text { of theory- } \\
\text { based online } \\
\text { self- } \\
\text { management } \\
\text { support } \\
\text { programs for } \\
\text { T2DM have }\end{array}$ \\
\hline
\end{tabular}




\begin{tabular}{|c|c|c|c|c|c|c|}
\hline & $\begin{array}{l}\text { predefined health } \\
\text { outcomes. }\end{array}$ & & & & $\begin{array}{l}\text { providing information } \\
\text { on consequences of } \\
\text { behavior, barrier } \\
\text { identification/problem } \\
\text { solving, } \\
\text { and self-monitoring of } \\
\text { behavior. These BCTs } \\
\text { were also linked to } \\
\text { positive outcomes for } \\
\text { health behavior } \\
\text { change, psychological } \\
\text { well-being, or clinical } \\
\text { parameters. }\end{array}$ & $\begin{array}{l}\text { been } \\
\text { reportedusing } \\
\text { only a select } \\
\text { number of } \\
\text { BCTs. The } \\
\text { development } \\
\text { of future } \\
\text { online self- } \\
\text { management } \\
\text { interventions } \\
\text { should be } \\
\text { based on the } \\
\text { use of } \\
\text { theories and } \\
\text { BCTs and } \\
\text { should be } \\
\text { reported } \\
\text { accurately. }\end{array}$ \\
\hline $\begin{array}{l}\text { Ali et al } \\
2011\end{array}$ & $\begin{array}{l}\text { To assess the } \\
\text { quantifiable and } \\
\text { qualitative impacts } \\
\text { of combined EMR- } \\
\text { CDSS tools on } \\
\text { diabetes }\end{array}$ & $\begin{array}{l}\text { Physician } \\
\text { performance } \\
\text { and patient } \\
\text { outcomes }\end{array}$ & $\begin{array}{l}\text { Applicability } \\
\text { in However, } \\
\text { care delivery } \\
\text { in low- and } \\
\text { middle- } \\
\text { income } \\
\text { countries } \\
\text { (LMICs) } \\
\text { personal } \\
\text { factors. } \\
\text { While } \\
\text { electronic } \\
\text { medical } \\
\text { records } \\
\text { (EMR) and } \\
\text { computerized } \\
\text { clinical } \\
\text { decision- } \\
\text { support } \\
\text { systems } \\
\text { (CDSS) }\end{array}$ & $\begin{array}{l}33 \text { studies } \\
\text { met inclusion } \\
\text { criteria }\end{array}$ & $\begin{array}{l}\text { Among predominantly } \\
\text { experimental study } \\
\text { designs, process } \\
\text { improvements were } \\
\text { consistently observed } \\
\text { along with small, } \\
\text { variable } \\
\text { improvements in risk- } \\
\text { factor control, } \\
\text { compared with } \\
\text { baseline and/or } \\
\text { control groups (where } \\
\text { applicable). }\end{array}$ & \\
\hline $\begin{array}{l}\text { Dalton } \\
\text { et al } \\
2008\end{array}$ & $\begin{array}{l}\text { To review current } \\
\text { research on online } \\
\text { information for } \\
\text { adults with type } 2 \\
\text { diabetes. } \\
\text { To determine the } \\
\text { potential impact of } \\
\text { this mode of } \\
\text { dissemination on } \\
\text { professional } \\
\text { dietetic practice. }\end{array}$ & $\begin{array}{l}\text { Telediabetes } \\
\text { is a form of } \\
\text { telemedicine } \\
\text { used to } \\
\text { provide } \\
\text { information } \\
\text { and client } \\
\text { care to } \\
\text { people with } \\
\text { diabetes. }\end{array}$ & $\begin{array}{l}\text { Cellular } \\
\text { telephones } \\
\text { and/or } \\
\text { computers }\end{array}$ & $\begin{array}{l}\text { Nine articles } \\
\text { meeting the } \\
\text { inclusion } \\
\text { criteria were } \\
\text { identified, } \\
\text { critiqued, } \\
\text { and } \\
\text { summarized. }\end{array}$ & $\begin{array}{l}\text { Studies varied greatly } \\
\text { in breadth and scope; } \\
\text { consequently, few } \\
\text { general conclusions } \\
\text { could be drawn about } \\
\text { telediabetes } \\
\text { programs. } \\
\text { Telediabetes } \\
\text { programs were } \\
\text { discussed in the } \\
\text { context of soundness, } \\
\text { effectiveness, cost- } \\
\text { effectiveness, and } \\
\text { practical } \\
\text { characteristics. } \\
\text { Trends indicated a } \\
\text { promising future for } \\
\text { telediabete }\end{array}$ & $\begin{array}{l}\text { Dietitians should } \\
\text { view telemedicine } \\
\text { as a viable tool } \\
\text { for service } \\
\text { delivery and } \\
\text { increase their } \\
\text { knowledge, } \\
\text { competency, } \\
\text { advocacy, and } \\
\text { research efforts } \\
\text { in this area. }\end{array}$ \\
\hline
\end{tabular}




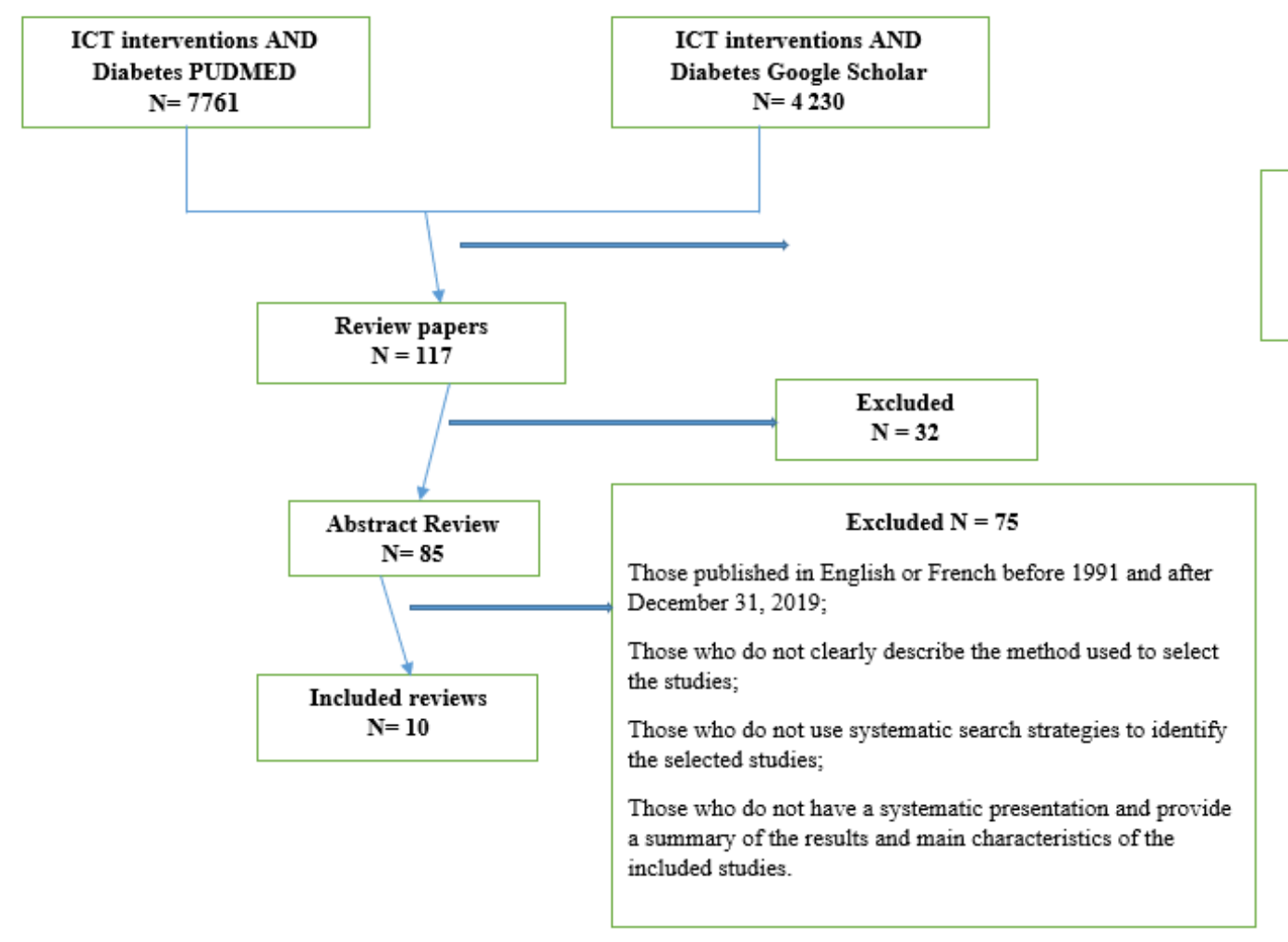

By excluding : Articles not corresponding to the research objective and duplicates $\mathrm{N}=10930$

\section{Figure 1}

Records selection processes and results 